\title{
A COMPANHIA DE PERNAMBUCO E PARAÍBA E O FUNCIONAMENTO DO TRÁFICO DE ESCRAVOS EM ANGOLA (1759-1775/80)*
}

Maximiliano M. Menz ${ }^{* *}$

\begin{abstract}
s companhias de comércio criadas por iniciativa de Sebastião $\triangle$ José de Carvalho e Mello, no final da década de 1750, foram 1 um dos mais importantes capítulos da história econômica colonial portuguesa da segunda metade do século XVIII. Seja pela introdução e estímulo à produção mercantil do algodão, seja pela integração definitiva da região do Grão Pará e Maranhão ao mercado atlântico, ou ainda pelas mudanças institucionais e na organização dos grupos mercantis portugueses, estas empresas foram um marco na transição entre a depressão aurífera e a recuperação da agricultura de exportação no final do século. Não bastasse sua importância, pela ligação com o Estado e a administração pública portuguesa, produziram e guardaram uma imensa coleção de documentos de cunho contábil que permitem deslindar a organização do comércio atlântico em seus três ramos: o africano, o europeu e o americano.
\end{abstract}

Mesmo assim, foram poucos os estudos sobre elas. Até agora, apenas a Companhia do Grão Pará e Maranhão foi devassada pelos trabalhos mais abrangentes de Manuel Nunes Dias e de Antônio Carreira, enquanto que a Companhia Geral de Pernambuco e da Paraíba (CGPP)

\footnotetext{
O autor agradece aos pareceristas anônimos que contribuíram para o melhoramento do artigo. ** Professor da Universidade Federal de São Paulo.

E-mail: maxmacmenz@hotmail.com
} 
foi estudada apenas por José Ribeiro Jr., além do capítulo de menor fôlego de Antônio Carreira sobre ela no livro As companhias pombalinas. ${ }^{1}$ Mais recentemente, monografias e artigos abordaram alguns temas relacionados às companhias, por exemplo, a sua relação com as populações coloniais, mas não chegaram a retornar aos seus dados contábeis. ${ }^{2}$

Particularmente sobre a Companhia de Pernambuco e da Paraíba, os estudos existentes não abrangem com o devido cuidado cada ramo do negócio do Atlântico. No caso do tráfico de escravos operado pela Companhia, o trabalho de Carreira levantou os números de almas exportadas, abordou as rotas, tratou da origem étnica dos escravos, mas pouco disse a respeito da organização do negócio do ponto de vista do financiamento e da sua organização na costa da África. Já o livro de José Ribeiro Jr. apresentou alguns dados, mas também não discutiu os temas que serão explorados aqui.

O presente artigo limita-se, portanto, ao estudo das atividades mercantis da Companhia de Pernambuco e da Paraíba no seu ramo africano. Mais precisamente: pretende estudar o financiamento das atividades no resgate de escravos em Angola, ${ }^{3}$ apresentando para isto um levantamento quantitativo das cargas importadas por Luanda e das conjunturas do negócio, fazendo ainda algumas considerações sobre a sua lucratividade. As operações da Companhia serão encaradas como uma amostragem do comércio angolano em geral, pois, como pretendo demonstrar, apesar das inovações na organização da Companhia (companhia por ações, monopólio do comércio), há uma tendência a repetir as experiências prévias no que diz respeito às rotas e carregações. Nessa

\footnotetext{
1 José Ribeiro Jr., Colonização e monopólio no Nordeste brasileiro, São Paulo: Hucitec, 2004; e Antônio Carreira, As companhias pombalinas, Lisboa: Presença, 1983.

2 Por exemplo, Érika S. A. Carlos, "O fim do monopólio: a extinção da Companhia Geral de Pernambuco e Paraíba" (Dissertação de Mestrado, Universidade Federal de Pernambuco, 2001). Sigo a documentação da Companhia e boa parte dos registros alfandegários que designam por "Angola" o comércio feito através do porto de Luanda. Esta designação parece ser comum no Império português durante o século XVIII, pois, de acordo com Miller, enquanto nas colônias das demais nações europeias os escravos denominados Angola diziam respeito a todos os indivíduos resgatados ao sul do Cabo Lopes, no Brasil eram designados por "Angola" os escravos despachados por Luanda. Não pretendo generalizar o "modelo" de funcionamento do tráfico discutido aqui para outras zonas como Loango, Cabinda e Benguela. Joseph Miller, "África Central durante a era do comércio de escravizados, de 1490 a 1850", in Linda Heywood (org.), Diáspora negra no Brasil (São Paulo: Contexto, 2010), pp. 38-42.
} 
direção, desenvolvo uma hipótese, formulada originalmente por Joseph Miller, de que eram os homens de negócio sediados em Portugal que financiavam o tráfico em Angola. ${ }^{4}$

Uma das fontes principais do artigo são os livros de demonstrações da Junta de Lisboa, verdadeiros balanços das suas operações entre 1759-1775. Trata-se de uma documentação bastante uniforme, ainda que existam mudanças no modo de serem lançadas as operações no

4 Joseph Miller, Way of Death: Merchant Capitalism and the Angolan Slave Trade, 1730-1830, Winscosin: The Universisty of Winscosin Press, 1988. A historiografia tem avançado bastante no debate a respeito das relações entre o comércio de escravos e as comunidades africanas do interior, o impacto do tráfico sobre a demografia e sobre as guerras no interior de Angola e demais regiões da África Centro-Ocidental. Ver por exemplo: John Thornton, "Early Kongo Portuguese Relations: A New Interpretation", History in Africa, v. 8 (1981), pp. 183-204; John Thornton, "As guerras civis no Congo e o tráfico de escravos: a história e a demografia de 1718 a 1844 revisitadas", Estudos Afro-Asiáticos, n. 32 (1997), pp. 55-74, John Thornton, Cannibals, Witches, and Slave Traders in the Atlantic World. The William and Mary Quarterly, Third Series, v. 60, n. 2 (2003), pp. 273-94; Roquinaldo Ferreira, "Transforming Atlantic Slaving: Trade, Warfare and Territorial Control in Angola, 1650-1800" (Tese de Doutorado, Universidade da Califórnia, 2003); José Curto, Raymond Gervais, "A dinâmica demográfica de Luanda no contexto do tráfico de escravos do Atlântico Sul, 1781-1844”, Topoi, n. 4 (2002), pp. 85-138. Ver também os trabalhos mais gerais de John Thornton, "The Portuguese in Africa", in Francisco Bethencourt e Diogo Curto, Portuguese Oceanic Expansion, 1400-1800 (Cambridge: Cambridge University Press, 2007); Jan Vansina, "O Reino do Congo e seus vizinhos"; e Marian Malowist, "A luta pelo comércio internacional e suas implicações para a África”, ambos in Allan Bethwell (org.), História da África, v. V (Brasília: UNESCO, 2010), pp. 647-695 e pp. 1-27; David Birmgham, Trade and Conflict in Angola. The Mbundu and their Neighbours under the Influence of the Portuguese 1483-1790. Oxford: Clarendon Press, 1966. Paradoxalmente são poucas as contribuições recentes sobre a organização financeira do negócio durante o século XVIII, especialmente se considerarmos que existem muitas fontes contábeis e alfandegárias nos arquivos portugueses. Os trabalhos mais abrangentes a este respeito e sobre o século XVIII permanecem sendo os de Joseph Miller, "Imports at Luanda, Angola 1785-1823”, in G. Pasch e A. Jones, Figuring African Trade (Berlin: Reimer, 1986); Joseph Miller, "Slave Prices in the Portuguese Southern Atlantic, 1600-1830", in Paul Lovejoy (org.), Africans in Bondage. Studies in Slavery and Slave Trade (Winscosin: African Studies Program; University of Winscosin, 1986), pp. 43-77; e Joseph Miller, "Capitalism and Slaving: The Financial and Commercial Organization of the Angolan Slave Trade, According to the Accounts of Antonio Coelho Guerreiro (1684-1692)" The International Journal of African Historical Studies, v. 17, n. 1 (1984). Também José Curto trabalhou com o material alfandegário de Luanda em seu estudo sobre o papel das bebidas alcoólicas no tráfico: José Curto, Álcool e escravos. O comércio luso-brasileiro do álcool em Mpinda, Luanda e Benguela durante o tráfico atlântico de escravos (c. 1480-1830) e o seu impacto nas sociedades da África Central e Ocidental, Lisboa: Vulgata, 2002. Existem ainda algumas obras mais recentes que tratam do século XVII: Linda Newson e Susie Minchin, From Capture to Sale: The Portuguese Slave Trade to Spanish America in the early Seventeenth Century, Leiden/Boston: Brill, 2007; e Filipa R. Silva, "Crossing Empires: Portuguese, Sephardic, and Dutch Business Networks in the Atlantic Slave Trade, 1580-1640”, The Americas, v. 68, n. 1 (2011), pp. 7-32. 
decorrer do tempo. Todavia, tais registros possuem problemas graves, como já havia notado Antônio Carreira, pois não cobrem todo o período de atuação da Companhia, que se estendeu até 1787, e nem sequer abordam os três últimos anos de monopólio. Não bastasse isto, existem lacunas enormes nos livros, particularmente nas cargas enviadas de Pernambuco para Angola e de Angola para Pernambuco, isto provavelmente explica a distorção apontada por Carreira, que compulsou outras fontes, entre os seus números e os dos trabalhos anteriores de Edmundo Correia Lopes e Cunha Saraiva. ${ }^{5}$

Além disso, os números reunidos por Antônio Carreira e os do levantamento mais recente do The Transatlantic Slave Trade Database (TSTD), são diferentes das listas de exportações de escravos fornecidas pelos administradores do contrato de Angola (ver Tabela 1, colunas B e C). ${ }^{6}$ Não está clara a origem da distorção, sonegação, sub-registro por parte dos administradores do contrato, e diferenças entre as datas da viagem e a do registro contábil podem estar entre as razões. Mesmo assim, vale a pena apresentar as diferenças.

Somando os anos em que existem dados para as três fontes chegase ao seguinte resultado A: 22.678, B: 22.552, C: 24.222 . Uma quarta fonte no que diz respeito ao comércio de escravos é a alfândega de Pernambuco, que registrou a importação de 30.202 cabeças de Angola entre 1760 e 1777, contra as 32.481 levantadas pelo TSTD durante o mesmo período. ${ }^{7}$ As diferenças entre as fontes são em torno de $10 \% \mathrm{e}$, ainda que não inviabilizem a análise quantitativa, revelam a dificuldade em se trabalhar com os dados da Companhia.

Cf. Carreira, As companhias pombalinas, p. 236. Sobre as lacunas nos livros de demonstração ver infra o comentário a respeito dos cálculos de importação e de lucratividade do negócio.

David Eltis et. al. "Voyages: The Trans-Atlantic Slave Trade Database" (2008), www.slavevoyages. Ressalte-se que o TSTD não é uma fonte totalmente independente e que uma boa parte de seus dados referentes a Pernambuco no período baseia-se nas mesmas fontes do artigo.

7 O TSTD não registra exportações no ano de 1760, pois o filtro utilizado foi o proprietário das embarcações (a Companhia) e no ano de 1760 ela pode ter fretado embarcações para carregar os escravos para Pernambuco. Em todo o caso, no livro de demonstrações consta uma carga enviada de Lisboa para Angola em 1759 que certamente deve ter produzido uma exportação de escravos no ano seguinte: ANTT, CGPP, Livros de demonstrações, L-394. Os números da alfândega de Pernambuco estão em certidões, inclusas em AHU, cx. 130, doc. 9823, 13/07/ 1778, José César de Meneses. 
Tabela I: Escravos exportados de Angola pela Companhia de Pernambuco (1761-1787)

\begin{tabular}{rrrr}
\hline & $\mathbf{A}$ & $\mathbf{B}$ & $\mathbf{C}$ \\
$\mathbf{1 7 6 1}$ & & 1.765 & 2.308 \\
$\mathbf{1 7 6 2}$ & 1.666 & 1.652 & 1.694 \\
$\mathbf{1 7 6 3}$ & 2.698 & 2.685 & 3.349 \\
$\mathbf{1 7 6 4}$ & 1.834 & 1.824 & 1.834 \\
$\mathbf{1 7 6 5}$ & 3.217 & 3.151 & 3.217 \\
$\mathbf{1 7 6 6}$ & 2.380 & 2.376 & 1.973 \\
$\mathbf{1 7 6 7}$ & 2.649 & 2.636 & 2.445 \\
$\mathbf{1 7 6 8}$ & & & 2.538 \\
$\mathbf{1 7 6 9}$ & 758 & 754 & 788 \\
$\mathbf{1 7 7 0}$ & 1.685 & & 2.119 \\
$\mathbf{1 7 7 1}$ & 1.704 & 1.704 & 1.227 \\
$\mathbf{1 7 7 2}$ & 1.580 & 1.580 & 2.366 \\
$\mathbf{1 7 7 3}$ & & & 1.266 \\
$\mathbf{1 7 7 4}$ & 2.082 & 2.080 & 2.496 \\
$\mathbf{1 7 7 5}$ & 2.110 & 2.110 & 2.833 \\
$\mathbf{1 7 7 6}$ & & & 2.263 \\
$\mathbf{1 7 7 7}$ & & & 1.381 \\
$\mathbf{1 7 7 8}$ & & & 977 \\
$\mathbf{1 7 7 9}$ & & & 1.175 \\
$\mathbf{1 7 8 0}$ & & & 1.118 \\
$\mathbf{1 7 8 1}$ & & & 1.033 \\
$\mathbf{1 7 8 2}$ & & & 1.744 \\
$\mathbf{1 7 8 3}$ & & & 2.920 \\
$\mathbf{1 7 8 4}$ & & & 1.094 \\
$\mathbf{1 7 8 5}$ & & & 357 \\
$\mathbf{1 7 8 6}$ & & & 353 \\
$\mathbf{1 7 8 7}$ & & & \\
\hline
\end{tabular}

Coluna A: exportações segundo Miller, table 1, pp. 91-92. Coluna B: exportações segundo os mapas preparados pelos administradores de Angola ${ }^{8}$ (AHU, cx.45, doc. 34, cx. 46, doc. 1, cx.48, doc. 6 , cx. 50 , doc. 2 , cx. 51 , doc. 18 , cx. 52 , doc. 5 , cx. 53 , doc. 84 , cx. 56 , doc. 8 , cx. 60 , doc. 23 , cx. 61, doc. 2). Coluna C: exportações segundo o TSTD, consultado em 25/05/2011.

Miller utilizou, provavelmente, as mesmas fontes e a diferença deve ser resultado de eu não ter contabilizado "as crias", mas apenas os escravos adultos. Cf. Joseph Miller, "The Numbers, Origins, and Destinations of Slaves in the Eighteenth-Century Angolan Slave-Trade", in Joseph Inikori e Stanley L. Engerman (orgs.), The Atlantic Slave Trade: Efects on Economies, Societies and Peoples in Africa, (Durham: Duke University Press, 1992), p. 77-116. 
Ou seja, ainda é necessário um estudo que levante todas as operações relacionadas ao tráfico, dispersas na imensa coleção de livros e documentos avulsos da Companhia, que, como sugeria Carreira em 1982, organize "fichas individualizadas para cada mercadoria e por ano, por carregações e respectivos preços, consoantes os destinos".

Mesmo assim, penso que os dados da Companhia, ainda que incompletos, estão entre as fontes mais importantes para o estudo do funcionamento do tráfico em Angola, pois é o conjunto mais abrangente de operações no negócio de escravos que se conhece até o momento. Mas, para utilizar estes dados, foi necessário desmembrar o trato quantitativo: no cálculo sobre as importações de Angola, visando discutir as operações de financiamento do tráfico de escravos e as suas flutuações durante o período, foram utilizados os já referidos Livros de Demonstração, procurando completar as lacunas com o Livro Mestre da Companhia com o registro do enfardamento de mercadorias em Lisboa e com o copiador de cartas da Junta de Lisboa com a administração de Angola. ${ }^{10}$ Para controle destes dados e para completar as lacunas referentes aos anos de 17601761, quando não foi possível levantar o número de cargas enviadas de Pernambuco para Angola, utilizei os números de Corcino Santos sobre a entrada de embarcações no porto de Luanda com origem em Pernambuco. Cheguei assim a um número muito próximo ao de Carreira, que reuniu 125 viagens de Angola para Pernambuco "e outras tantas de retorno" entre 1759 e 1787, ao passo que, em minha pesquisa, foi possível levantar 105 cargas para Angola entre 1759 e 1780. Considerando que entre 1781 e 1787 foram enviadas mais algumas carregações, acredito que os resultados alcançados aqui são bastantes seguros. ${ }^{11}$ Do mesmo modo, o número assemelha-se aos do TSTD que registra 102 viagens entre $1761 \mathrm{e}$ 1780 , incluindo duas em que foram desembarcados escravos no Rio de

\footnotetext{
Carreira, As companhias pombalinas, p. 8.

10 Arquivo Nacional da Torre do Tombo, doravante ANTT, Companhia Geral de Pernambuco e Paraíba (CGPP), Junta de Lisboa, Livros de Demonstrações $(394,395)$, ANTT, CGPP, Junta de Lisboa, Livros Mestre (470, 471), ANTT, CGPP, Junta de Lisboa, Livro de Enfardamentos, 484, ANTT, CGPP, Junta de Lisboa, Copiador de Cartas, 290.

11 Pelo copiador de cartas da Junta sabemos que foram enviadas mais três cargas de Lisboa depois de 1781, além disso, a administração de Pernambuco enviava entre duas a três embarcações anuais no período imediatamente anterior ao fim do monopólio. Considerando uma
} 
Janeiro, ligeiramente inferior aos meus resultados por causa das diferenças no recorte (as balizas temporais do TSTD são o ano de descarga dos escravos) e da inexistência de viagens naquele registro no que se refere ao ano de 1760 (ver nota 7). ${ }^{12}$

Para estimar a lucratividade e calcular a "balança comercial" da administração de Angola, relacionei exclusivamente os Livros das Demonstrações. Esta documentação cobre um pouco mais da metade das negociações totais da Companhia e se encerra antes mesmo do fim do monopólio; mesmo assim, pode ser vista como uma amostra relativamente equilibrada, pois ao todo registra 72 operações de importação incluindo cargas originadas em Lisboa (24) e Pernambuco (48) - e 71 operações de exportação, para Pernambuco (69) e para o Rio (2).

Do copiador e de alguns documentos avulsos do Arquivo Histórico Ultramarino procurei retirar as informações qualitativas sobre o negócio.

Criada pelo Alvará de 13 de agosto de 1759, a Companhia de Pernambuco e da Paraíba fez parte da reorganização institucional promovida pelo Marquês de Pombal na organização do comércio português. Foi precedida pela criação das companhias do Maranhão e do Grão Pará, da Agricultura e Vinhas do Alto Douro, e da menos bem sucedida Companhia da Ásia Portuguesa; estando associada ainda à criação da Junta de Comércio e à expulsão dos comissários volantes do Brasil. Fundamentalmente, as medidas favoreciam os grandes capitalistas da praça de Lisboa, demarcando o que K. Maxwell chamou de "nacionalização da economia luso-brasileira". ${ }^{13}$

possível redução no negócio da Companhia, é provável que Pernambuco tenha enviado algo entre sete ou quatorze cargas entre 1781-1787. Note-se ainda que uma parte dos registros com os quais trabalhei refere-se apenas às cargas e não às embarcações, portanto, não creio que exista uma correspondência total, como sugere Carreira, entre o número de viagens com escravos e o número de carregações para Angola.

12 Também pode ter pesado o fato de que nem todo registro de carga no livro de demonstrações diz respeito a uma viagem ou embarcação.

13 Kenneth Maxwell, Chocolate, piratas e outros malandros, São Paulo: Paz e Terra, 1999. Ver também José A. França, "Burguesia pombalina, nobreza mariana, fidalguia liberal", in Maria H. C. Santos, Pombal revisitado, v. I (Lisboa: Estampa, 1984), pp. 19-33. 
Entre os privilégios obtidos pela Companhia estava o "exclusivo para ela só fazer o comércio, que até agora se fez, vaga e exclusivamente das referidas Capitanias de Pernambuco e Paraíba para a Costa da África e portos dela" ${ }^{14}$ basicamente Costa da Mina e Angola, locais de onde tradicionalmente resgatavam-se escravos para Pernambuco. À junta de administração em Lisboa e às duas direções subordinadas em Pernambuco e no Porto, submetiam-se mais duas administrações: na Paraíba, ligada à direção de Pernambuco, e em Angola, controlada pela Junta de Lisboa. ${ }^{15}$

É notável que a forma de organização dos negócios, no que diz respeito ao tráfico de escravos, reproduzia padrões anteriores: em Angola, onde a presença lusitana era mais do que secular e onde já existia uma praça mercantil, articulada com a praça de Lisboa, era estabelecida uma administração diretamente ligada à Junta Central; na Costa da Mina, onde o resgate era feito principalmente pelos capitães de navios das praças da América portuguesa, nem procurador havia ${ }^{16}$ e o negócio naquela costa era operado exclusivamente pela direção de Pernambuco.

A administração de Angola, estabelecida em Luanda por volta de 1760, possuía dois administradores: nos primeiros anos, Raymundo Jalamá e Francisco Bruno de Lemos. Os administradores recebiam cargas de Lisboa e Pernambuco com as quais deveriam operar o resgate, comprando escravos dos comerciantes e pumbeiros de Luanda, também eram responsáveis pelas expedições dos escravos que partiam para

${ }^{14}$ Estatuto da Companhia de Pernambuco e Paraíba, artigo 26, apud: Carreira, As companhias pombalinas, p. 223.

15 Ribeiro Jr., Colonização e monopólio, p. 85.

16 Os portugueses possuíam feitorias em Jakin e Ouidah, mas comerciavam também com as feitorias das outras nações europeias: cf. Robin Law e Kristin Mann, "West Africa in the Atlantic Community: The Case of the Slave Coast", The William and Mary Quarterly, Third Series, v. 56, n. 2, African and American Atlantic Worlds (1999), pp. 307-34; Robin Law, The gold trade of Whydah in the seventeen and eighteenth centuries, in David Henige e D. McCaskie (orgs.), West African Economic and Social History. Studies in memory of Marion Johnson (105-118) (Madison: University of Wisconsin, 1990), pp. 105-18. Sobre as diferenças do tráfico em Angola e na Costa da Mina, cf. Gustavo Acioli Lopes e Maximiliano Menz, "Resgate e mercadorias: uma análise comparada do tráfico luso-brasileiro em Angola e na Costa da Mina (século XVIII)". Afro-Ásia, n. 37 (2008), pp. 43-73. Ver também Gustavo Acioli Lopes, "Negócio da Costa da Mina e comércio atlântico - tabaco, açúcar, ouro e tráfico de escravos: Pernambuco (1654-1760)" (Tese de Doutorado, USP, 2008); Miller, Way of Death. 
Pernambuco; recebiam salários, além de comissões sobre as cargas, que deveriam ser de $5 \%$ a venda, $1,5 \%$ de cobrança e $1,5 \%$ de remessa. $\mathrm{Na}$ essência, como dizia a Junta de Lisboa "o projeto do negócio de Angola é trocar fazendas por escravos e que as mesmas fazendas que desta se remetem hajam de suprir as expedições que as foram de Pernambuco". ${ }^{17}$ Deste modo, o tráfico era plenamente verticalizado e a maior parte dos lucros contabilizados com as cargas de Angola era realizada apenas em Pernambuco com a venda final dos escravos.

No entanto, os balanços e a correspondência da Companhia mostram que as operações foram ligeiramente mais complexas. Nos primeiros anos a administração em Angola necessitou tomar crédito em letras, provavelmente para comprar alguns produtos de origem americana. ${ }^{18}$ Também durante cinco ocasiões os administradores compraram mercadorias asiáticas diretamente das Naus da Índia, aproveitando-se da autorização do comércio com estas embarcações entre 1761 e 1772. Por último, como será demonstrado em seguida, a Companhia realizou parte de seus lucros com letras.

Além disso, os administradores de Angola não se furtavam a fazer negócios por conta própria, como mostram as queixas da Junta durante a década de $1770 .{ }^{19}$ Em compensação, em duas ocasiões, a Junta de Lisboa enviou cargas a comerciantes de Angola, Manoel Bessa Teixeira e João Alves Ferreira, que não estavam diretamente engajados na administração. ${ }^{20}$

Antes de prosseguirmos na análise dos dados e tendo em vista o objetivo deste artigo, é importante verificar a representatividade da Companhia no conjunto das negociações angolanas. Para tanto, basta calcular a proporção das suas compras no total das exportações angolanas de escravos. Entre 1761 e 1778, enquanto durou o exclusivo, a ad-

\footnotetext{
17 ANTT, CGPP, Junta de Lisboa, Copiador de Cartas, L-290, 21/08/1762.

18 Não é possível quantificar o quanto foi utilizado em letras nestas primeiras operações, pois é provável que este valor tenha sido lançado na contabilidade junto com outras somas em dinheiro tomado em empréstimo. Mas, segundo a Junta, uma das primeiras cargas de escravos enviadas ao Brasil "[...] foi quase toda comprada a dinheiro, de que sacaram letras [...]". ANTT, CGPP, Junta de Lisboa, Copiador de Cartas, L-290, 06/11/1761.

19 ANTT, CGPP, Junta de Lisboa, Copiador de Cartas, L-290 19/06/1772 e 21/05/1773.

20 Cf. ANTT, CGPP, Junta de Lisboa, Enfardamentos, L-484.
} 
ministração de Angola foi responsável pela exportação de $26 \%$ dos escravos enviados de Luanda, com a sua participação girando anualmente entre 14 e $44 \%$ do total. ${ }^{21}$ No momento em que foi encerrado o exclusivo, as exportações da Companhia caíram em números absolutos e relativos (apenas 13\% do total), como era de se esperar; mas ainda ocorreram dois anos de grandes exportações (1782-1783). Creio que isto permite concluir que a Companhia de Pernambuco foi, provavelmente, a maior exportadora individual de escravos em Luanda no período, enquanto durou o monopólio, daí que as suas operações sejam um retrato ligeiramente fiel do negócio naquela região. ${ }^{22}$

Vejamos agora o conjunto das negociações da administração de Angola entre 1759-1775, segundo os balanços gerais da Companhia. Vale lembrar que estes balanços representam pouco mais da metade das operações da Companhia em Angola.

Os números do Gráfico 1 apresentam um contraste muito claro entre as exportações feitas pela administração de Angola que superam em mais de 331 contos as suas importações. Há de se considerar ainda que o já referido sub-registro do livro de demonstrações incide mais sobre as exportações, pois as ausências nas importações são principalmente de cargas de Pernambuco que mal ultrapassavam o valor de 2,7 contos por navio, enquanto as cargas enviadas de Angola eram de 16 contos em média. Retificando as importações pelos dados levantados em outras fontes (ver nota 10) chega-se a um valor de 993 contos (ver Tabela 2); procurando completar o valor das exportações de escravos pela estimativa da carga média de cada navio negreiro, chega-se ao valor de 1.683 contos, ou seja, as exportações ultrapassaram as importações em aproximadamente $69 \%$ entre 1759 e $1780 .^{23}$

${ }^{21}$ Curto, Álcool e escravos, quadros IV e VIII; e The Transatlantic Slave Trade Database (http:/ /www.slavevoyages.org/tast/database/search.faces, consultado em 25/05/2011).

22 Outro grande operador no tráfico era o contrato Angola. Como, durante a década de 1760, os contratadores estavam sediados em Portugal (Estevam José de Almeida e Domingos Dias da Silva), é muito provável que suas operações repetissem o padrão da CGPP, remetendo grandes cargas de Lisboa. No momento estou preparando um estudo sobre o contrato de Angola, utilizando para isto os livros contábeis de um dos contratadores. Ver ainda Miller, Way of Death, pp. 535-69.

23 Para se chegar a este valor presumiu-se que o número de operações de exportação teria sido igual ao de importação (105), segundo a já referida interpolação dos dados dos Livros de Demonstrações com outras fontes (ver a introdução do artigo). Daí multiplicou-se a diferença 


\section{Gráfico 1: Exportações e importações da administração de Angola,}

1759-1775

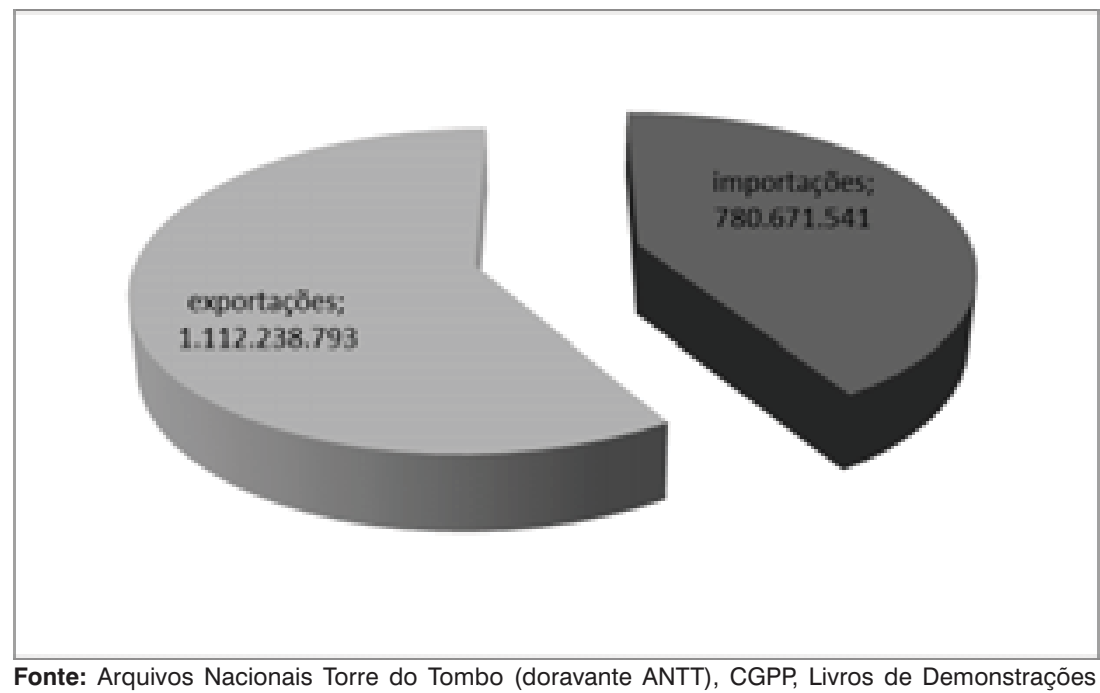
$(394,395)$

A razão desta aparente distorção é muito simples, os valores das cargas eram calculados pelos seus preços nos portos de origem, como fica claro pelo livro de enfardamentos da Companhia, de maneira que aos valores das importações devem ser somados os custos e os lucros das operações. ${ }^{24}$

Praticamente todas as exportações destinavam-se a Pernambuco, mas constam dois envios para o Rio de Janeiro. Não está clara a razão destas carregações, todavia, é possível que não tenham passado de experiências malsucedidas visando diversificar as operações da Companhia, uma vez que as cargas de escravos enviadas para Pernambuco resultavam em prejuízos ou em lucros muito pequenos (ver adiante). As

(34) entre este valor (105) e o número de operações de exportação registradas nas demonstrações (71) pela carga média das embarcações que faziam a rota Angola-Pernambuco (16.801.164 réis), para com isto completar o total exportado pela administração de Angola entre 1759 e 1780

24 ANTT, CGPP, Junta de Lisboa, Livro de Enfardamentos, L-484. 
Tabela 2: Importações da administração de Angola (em réis)

\begin{tabular}{|c|c|c|c|c|}
\hline & Pernambuco & Lisboa & Nau da Índia & Total \\
\hline 1759 & 0 & 18.826 .314 & 0 & 18.826 .314 \\
\hline 1760 & 16.206 .408 & 0 & 0 & 16.206 .408 \\
\hline 1761 & 13.505 .340 & 52.713 .993 & 0 & 66.219 .333 \\
\hline 1762 & 8.531 .585 & 70.117 .021 & 0 & 78.648 .606 \\
\hline 1763 & 11.157 .212 & 70.693 .119 & 0 & 81.850 .331 \\
\hline 1764 & 21.870 .331 & 45.424 .987 & 0 & 67.295 .318 \\
\hline 1765 & 7.641 .443 & 14.421 .681 & 0 & 22.063 .124 \\
\hline 1766 & 4.567 .559 & 23.453 .401 & 26.933 .570 & 54.954 .530 \\
\hline 1767 & 12.678 .941 & 50.104 .757 & 17.587 .452 & 80.371 .150 \\
\hline 1768 & 19.764 .789 & 40.958 .391 & 3.364 .674 & 64.087 .854 \\
\hline 1769 & 4.720 .552 & 41.558 .224 & 0 & 46.278 .776 \\
\hline 1770 & 8.459 .150 & 2.014 .050 & 0 & 10.473 .200 \\
\hline 1771 & 13.457 .344 & 30.556 .476 & 7.354 .200 & 51.368 .020 \\
\hline 1772 & 8.687 .735 & 0 & 0 & 8.687 .735 \\
\hline 1773 & 2.396 .657 & 0 & 0 & 2.396 .657 \\
\hline 1774 & 8.106 .071 & 143.882 .929 & 0 & 151.989 .000 \\
\hline 1775 & 7.665 .956 & 0 & 0 & 7.665 .956 \\
\hline 1776 & 3.731 .521 & 60.770 .963 & 0 & 64.502 .484 \\
\hline 1777 & 6.070 .535 & 47.411 .747 & 0 & 53.482 .282 \\
\hline 1778 & 4.441 .810 & 9.551 .542 & 0 & 13.993 .352 \\
\hline 1779 & 6.917 .609 & 15.482 .664 & 0 & 22.400 .273 \\
\hline 1780 & 9.300 .489 & 0 & 0 & 9.300 .489 \\
\hline Total & 199.879 .038 & 737.942 .259 & 55.239 .896 & 993.061 .193 \\
\hline$\%$ & $20 \%$ & $74 \%$ & $6 \%$ & \\
\hline
\end{tabular}

operações no Rio estavam sob o cuidado de um procurador que também era responsável pelo pagamento de algumas letras sacadas pelos administradores. ${ }^{25}$

O estudo das importações pode ser mais abrangente graças ao levantamento mais completo.

${ }^{25}$ Cf. ANTT, CGPP, Junta de Lisboa, Copiador de Cartas, L-290. 
Primeiro, uma conclusão óbvia: há um domínio completo de cargas originadas em Lisboa (74\%), em seguida estão as cargas enviadas pela administração de Pernambuco $(20 \%)$ e, por último, as compras feitas pelos administradores de mercadorias das Naus da Índia (6\%) (ver a última coluna da Tabela 2). Ainda que seja possível um viés nas operações da Companhia pelo seu caráter eminentemente reinol, estas proporções reforçam estimativas referentes ao período de 1796-1807 e demonstram que era através da Metrópole que era fornecida a maior parte das mercadorias para o resgate angolano. ${ }^{26}$

Aliás, se fosse mais rentável enviar produtos preferencialmente por Pernambuco ou comprá-los em Angola, a Companhia o faria. ${ }^{27}$ Isto fica bastante claro nas instruções da Junta de Lisboa sobre a compra de fazendas das Naus da Índia:

[...] esta junta presume que a esse porto [Luanda] hão de ir as Naus vindas de Goa, conforme as ordens de S. Maj., ordena a V. Mce. que das fazendas que elas trouxerem podem comprar as que bem lhe bastam para o sortimento anual do negócio que essa administração aí fizer e de sua importância sacar letras sobre esta junta com a maior extensão de tempo em que se puderem ajustar com os vendedores delas. ${ }^{28}$

26 Entre 1796 e 1807 a participação metropolitana no fornecimento de mercadorias para Angola teria ficado entre $54 \%$ e $60 \%$, e as cargas médias com origem em Portugal seriam de 73 contos de réis e as com origem na Bahia de apenas 12 contos de réis. Maximiliano M. Menz, "As 'Geometrias' do tráfico. O comércio metropolitano e o tráfico de escravos em Angola", Revista de História, n. 166 (2012), pp. 185-222. Ver ainda Lopes e Menz, "Resgate e mercadorias".

$27 \mathrm{Na}$ verdade, apenas a compra de produtos das Naus da Índia era rentável em Angola, pois ao comprar produtos europeus ou americanos na região era necessário pagar os lucros e os custos dos fornecedores de Lisboa e do Brasil. Como dizia a Junta, "faz uma tão grande diferença o expedir os navios com os produtos das carregações da Companhia a expedi-los com dinheiro de letras, que por este último modo quase que não faz conta alguma”. ANTT, CGPP, Junta de Lisboa, Copiador de Cartas, L-290, 13/01/1764. Como demonstrarei adiante a lucratividade da Companhia concentrava-se no fornecimento de fazendas e não na venda dos escravos.

28 ANTT, CGPP, Junta de Lisboa, Copiador de Cartas, L-290, 25/02/1763. Durante a década de 1760 a Coroa autorizou que as naus da Carreira da Índia tocassem em Luanda e vendessem mercadorias no local. De acordo com os registros alfandegários dos despachos das cargas das Naus da Índia, havia um número muito grande de despachantes de mercadorias, incluindo os administradores da CGPP e do contrato de Angola ligados a mercadores metropolitanos. O maior despachante individual foi Antonio José da Gama e Cia. que despachou 22 contos entre 1766 e 1772 (3,14 contos por ano). AHU, Avulsos, Angola, cx. 50, doc. 16, 14/06/1766, AHU, Avulsos, Angola, cx. 51, doc. 71, 1767 AHU, Avulsos, Angola, cx. 55, doc. 53, 12/08/1772, AHU, Avulsos, Angola, cx. 55, doc. 89, 07/12/1771, AHU, Avulsos, Angola, cx. 56, doc. 70, 16/08/1772. Nas fontes alfandegárias e contábeis com as quais trabalhei não existem 
Pretendendo liquidar os negócios em 1785, a Junta determinou que os navios que faziam o trajeto Luanda-Pernambuco deveriam carregar em Recife produtos para obter em Angola 1/3 de sua lotação e, completando o resto com escravos dos particulares, vender carga e casco no Rio de Janeiro. Todavia, alguns meses depois, a Junta de Lisboa retificava:

[...] refletindo depois esta junta que aqueles administradores não podiam fomentar com gêneros do país e próprios do consumo desse Reino aquela terceira parte da lotação de cada uma das embarcações [...] por não haver naquela Capitania [de Pernambuco] [...]. ${ }^{29}$

Apesar do predomínio reinol no fornecimento de mercadorias, o mesmo não ocorria no número de embarcações que fazia o resgate. Ao todo, levantei 31 cargas enviadas de Lisboa para Luanda e 74 cargas de Pernambuco para Luanda, deste modo, a carga média originada em Portugal era de 23 contos, enquanto que a carga média do Brasil era de 2,7 contos. Estes valores, porém, não representam a média das cargas por embarcação de modo exato, pois os registros contábeis eram sobre as carregações e nem sempre constava o nome do navio.

Este problema é mais grave para os seis primeiros anos de existência da Companhia, quando não foram registrados os nomes das em-

indícios que comprovem a tese de Roquinaldo Ferreira ("Transforming Slaving") de que os mercadores do Brasil controlavam o comércio de têxteis indianos em Angola, pelo menos no que se refere à segunda metade do século XVIII. Ademais o acesso dos mercadores do Brasil ao oriente se restringia a Moçambique. Luís Frederico Dias Antunes, "A influência africana e indiana no Brasil na virada do século XVIII: escravos e têxteis, in João Fragoso, Jucá Sampaio e Adriana Campos (orgs.), Nas rotas do Impéro: eixos mercantis e relações sociais no mundo português (Vitória: EDUFES, 2006), pp. 148-49. Os estudos de Vitorino Magalhães Godinho, Paulo Guinote e Jorge Pedreira mostram a grande vitalidade do comércio metropolitano com a Índia na segunda metade do século XVIII: Vitorino Magalhães Godinho, "Os portugueses e a 'Carreira da Índia' (1497-1810)", in Mito e mercadoria, utopia e prática de navegar, séculos XIII-XVIII (Lisboa: Difel, 1990), p. 344; Paulo Guinote, "India Route Project: Ascensão e declínio da carreira da Índia", in http://nautarch.tamu.edu/shiplab/, Nautical Archaeology Program, Texas A\&M University, 2003; Jorge Pedreira, Os Homens de Negócio da Praça de Lisboa de Pombal ao Vintismo (1755-1822). Diferenciação, reprodução e identificação de um grupo social, Lisboa: Universidade Nova de Lisboa, 1995, pp. 339-41. Deste modo, pela comparação entre os dados das balanças de comércio portuguesas e os registros de importação de Luanda é possível estimar que em torno de $76 \%$ das importações angolanas deste tipo de produto tinham origem em Portugal entre 1798 e 1805. Cf. Menz, “As 'Geometrias’ do tráfico”, p. 197.

29 ANTT, CGPP, Junta de Lisboa, Copiador de Cartas, L-290, 14/06/1785, ver as instruções originais na correspondência de 08/02/1785. 
barcações e, ademais, o aluguel de espaços nas embarcações de outros proprietários parece ter sido mais comum. Foi o caso de uma carga de 1.413.774 réis em um navio da Companhia do Grão Pará e do Maranhão em $1765 .^{30}$ Por outro lado, também a Companhia de Pernambuco deveria tomar fretes nas três pontas do negócio; apesar de não ser possível verificar isto por causa do modo como eram registrados os fretes na contabilidade da empresa, mas é certo que depois de 1780 a Junta de Lisboa instruiu os administradores a tomar e a oferecer fretes em Angola. ${ }^{31}$ Em todo o caso, as cargas médias por navio deveriam ser apenas ligeiramente superiores, visto que oferecer e tomar fretes "às partes" era secundário para a Companhia em Angola, ao menos durante o período em que durou o monopólio. ${ }^{32}$

Seja como for, os números da Companhia confirmam uma característica geral do negócio de Angola: as naves reinóis carregavam valores muito maiores que os barcos com origem no Brasil. Portanto, é ilusório concluir pelo domínio "brasílico" sobre o tráfico baseado na frequência de embarcações no porto de Luanda. ${ }^{33}$

30 ANTT, CGPP, Livro de Demonstrações, L-394.

31 ANTT, CGPP, Junta de Lisboa, Copiador de Cartas, L-290, 10/11/1781 e 31/12/1784.

32 Ao contrário do que ocorria com o comércio de atanados, açúcar e meios de sola. Cf. Ribeiro Jr., Colonização e monopólio, pp. 137-55. A presunção da baixa importância dos fretes no tráfico baseia-se no pequeno registro de fretes da Companhia do Grão Pará e Maranhão para Angola. ANTT, Companhia Geral do Grão Pará e Maranhão, Junta de Lisboa, Livro de carga dos navios por saída, L-75; e na comparação entre os valores dos fretes registrados nos livros de demonstrações da CGPP e o número de escravos carregados por algumas das embarcações segundo os mapas do AHU. Carreira afirma que entre 1782 e 1783 a Companhia carregou 2.436 escravos e 7 crias de particulares. Cf. Carreira, As companhias pombalinas, p. 234. Voltarei a tratar do negócio de fretes.

33 Vale acrescentar que em 1770, ao ser encerrado o contrato de Angola, a Junta de Fazenda do governo de Angola, preocupada com a diminuição no fornecimento de mercadorias para o resgate, elaborou um cálculo sobre a quantidade de importações necessárias para financiar as exportações de escravos. Segundo os membros da Junta, o produto anual das embarcações com origem nos portos brasileiros era de 160 contos (28\%), restando 404 contos que deveriam ser completados por embarcações vindas de Lisboa. AHU, cx. 54, doc. 28, Avulsos, Angola, 03/06/1770, anexada à correspondência de D. Francisco de Souza Coutinho. Luiz Felipe Alencastro é um dos que argumentam pelo domínio brasílico a partir da maior frequência de embarcações com origem no Brasil: O trato dos viventes: formação do Brasil no Atlântico Sul, São Paulo: Companhia das Letras, 2000, pp. 323-24. Também Mariana Candido conclui que os mercadores do Brasil dominavam o negócio em Benguela pelo mesmo argumento: "Merchants and the Business of the Slave Trade at Benguela, 1750-1850", African Economic History, n. 35 (2007), p. 8. Já Acioli Lopes demonstra que as poucas naus metropolitanas que frequentavam a Costa da Mina também levavam cargas mais valiosas que as embarcações com origem no Brasil: "Negócio da Costa da Mina", pp. 44-5. 
As diferenças no valor das cargas e suas consequências sobre a periodicidade do negócio revelam-se de modo mais claro se analisarmos graficamente a entrada de mercadorias ano a ano:

\section{Gráfico 2: Origem das importações da administração em Angola (réis)}

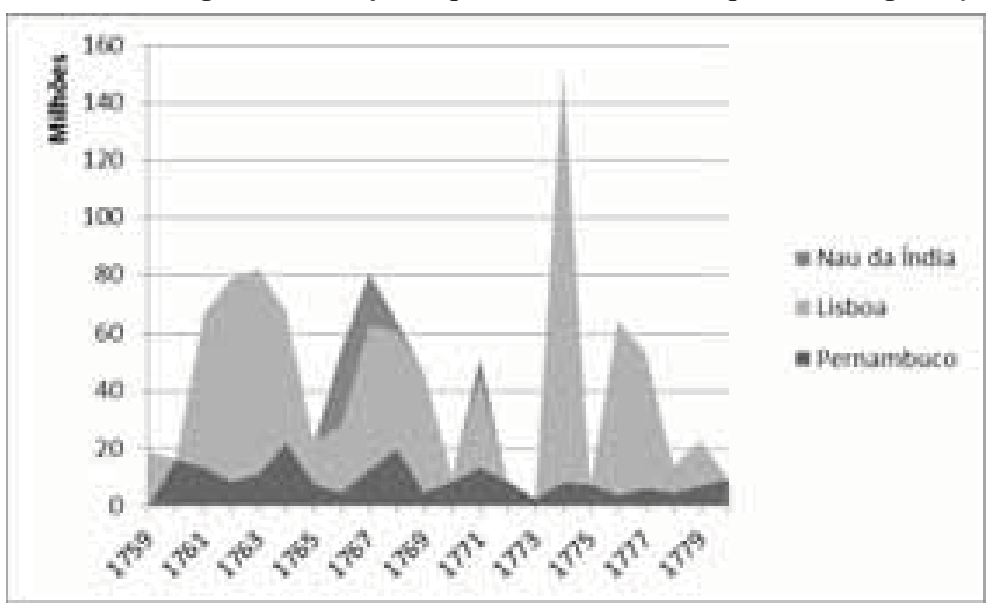

Fontes: ANTT, CGPP, Junta de Lisboa, Livros 394, 395, 470, 471, 290

A ligação entre Pernambuco e Angola era direta e anualmente entravam embarcações com jeribita para surtir as grandes cargas que a Companhia enviava desde Lisboa, sendo assim, as naves que faziam a rota Pernambuco-Angola deveriam carregar a maior parte dos escravos. Por sua vez, os navios da capital eram em menor número e, em alguns anos, chegou-se a interromper a ligação entre Luanda e Lisboa. Essa forma de organização do resgate, com grande separação no tempo entre o fornecimento de mercadorias no litoral e a realização em escravos, era típica do negócio de Angola. À baixa frequência de embarcações reinóis correspondia o uso regular do crédito; como retrucavam os administradores às críticas da Junta de Lisboa "sem cabedal empatado em dívidas é impossível que essa administração possa manear-se". ${ }^{34}$

34 ANTT, CGPP, Junta de Lisboa, Copiador de Cartas, L-290, 21/05/1773. As palavras são de autoria da Junta de Lisboa que comentava uma resposta da administração de Angola. Sobre o uso do crédito em Benguela ver Mariana Candido, "Merchants and the Business", pp. 13-7. 
Isto só era possível com o gerenciamento de estoques em Luanda, operação que era viável aos grandes monopolistas, fosse a Companhia, fossem os contratadores de Angola que dominaram boa parte do financiamento do negócio até $1770 .{ }^{35}$ Ao mesmo tempo, a irregularidade dos navios com origem em Portugal era possível pela natureza da carga, basicamente produtos manufaturados não perecíveis de alto valor e de maior facilidade para transporte e armazenamento, enquanto as cargas com origem no Brasil eram mais perecíveis e precisavam ser liquidadas rapidamente; esta é uma das razões porque as taxas de lucro das carregações com origem em Pernambuco eram tão inferiores (voltarei a este ponto). ${ }^{36}$

Vale dizer, porém, que, ao contrário do que sugere parte da historiografia sobre o tráfico, dívidas avultadas eram consideradas um problema pelos credores, como revela a correspondência da Junta de Lisboa:

o interesse da Companhia não consiste tanto em fazer um negócio muito avultado, quanto em fazê-lo com segurança e de modo que a todo tempo possa retirar seu cabedal e lucros [...] que procurem seguir de comum acordo as regras mais sólidas e mais comuns da melhor segurança [...] não aumentando as dívidas, nem demorando as cobranças e procurando quanto lhe for possível vender a troco de dinheiro, letras e cera e não confiando fazendas, nem contraindo dívidas com os negociantes dos moradores do sertão. ${ }^{37}$

O tema certamente merece ser mais bem investigado, mas acredito que uma das explicações para o uso generalizado de crédito é um reflexo do caráter particular da presença lusitana em África, frente às nações europeias. Sem uma manufatura competitiva e com pequena penetração no mercado asiático, Portugal conseguia controlar o tráfico em Angola graças a sua presença com fortalezas no hinterland de Luan-

\footnotetext{
35 Cf. Instituto de Estudos Brasileiros (IEB), Coleção Lamego, Códice 82, Francisco Inocencio Coutinho , 03/02/1770 e Joseph Miller, Way of Death.

36 A outra razão era que a concorrência no fornecimento de produtos americanos era muito maior, dada a maior frequência dos navios do Brasil.

37 ANTT, CGPP, Junta de Lisboa, Copiador de Cartas, L-290, 21/05/1773. Ver, por exemplo, Manolo Florentino, Em costas negras. São Paulo: Companhia das Letras, 1997. Uma discussão mais ampla sobre parte da historiografia brasileira está em Menz, “As 'geometrias' do tráfico".
} 
da e o exclusivo metropolitano. No entanto, nas feiras do interior a concorrência com as outras nações, ainda que indireta, fazia-se presente graças à ação dos pumbeiros que iam buscar mercadorias nos portos do norte, frequentados por franceses e ingleses. Sendo assim, o fornecimento de crédito seria um dos atrativos dos mercadores portugueses, mas este mercado funcionava, ainda que imperfeitamente, com a presença das instituições portuguesas (governador, ouvidor, juiz de fora) que garantiam, mesmo que de modo precário, a arrecadação das dívidas. ${ }^{38}$

No tocante às oscilações das importações durante o período estudado, é visível que elas acompanham a baixa nas exportações de escravos (Tabela 1). Naturalmente que não existe uma correspondência imediata no tempo entre importações e exportações, tendo em vista a estocagem de mercadorias nos armazéns em Luanda e o uso do crédito, é preciso lembrar que os administradores em Angola necessitavam ajustar a constituição dos banzos a serem enviados ao interior pelos pumbeiros com o fornecimento de mercadorias de resgate pelos navios da Companhia que, como se observa no gráfico 2, era bem irregular. Mesmo assim, podemos ver três períodos muito bem destacados: 1759-1769, com grandes importações de mercadorias e exportações de escravos, 1770-1778, em que se reduziu o movimento comercial da administração de Angola e depois de 1779, em que as operações da Companhia foram vagarosamente paralisadas.

\section{Lucros e prejuízos}

Um dos problemas fundamentais na análise das operações da Companhia de Pernambuco é a estimativa dos lucros. Como já foi dito, as demonstrações registram pouco mais da metade das operações no tráfico e a estimativa aqui terá de se basear unicamente nas negociações reunidas nestes livros.

\footnotetext{
${ }^{8}$ Miller tem uma opinião parecida sobre o crédito: Miller, "The Numbers, Origins", pp. 85-6. Naturalmente, as outras nações também faziam uso do crédito, por exemplo, as grandes firmas traficantes inglesas mantinham feitorias na costa da África que forneciam, mas creio que a baixa frequência de embarcações metropolitanas no tráfico angolano tornava mais comum o uso do crédito em Angola. Sobre o uso do crédito pelos ingleses, cf. Joseph Inikori, African and the Industrial Revolution in England: A study in international trade and economic development, Cambridge: Cambridge University Press, 2002, pp. 323-24.
} 
Além disto, o modo como eram lançados os lucros refletia a morosidade entre os envios das cargas e a chegada da notícia da realização. Assim, na maioria das vezes, era lançada uma estimativa dos ganhos no ano em que era registrada a carregação e apenas nos balanços seguintes era retificada a estimativa sob o registro "diferença entre o que se orçou e o que realmente rendeu em uma carga". ${ }^{39}$ Deste modo, o cálculo ideal seria separar cada carga e identificar os lucros reais por cada operação e, depois disto, fazer as somas e as decorrentes análises. No entanto, há uma dificuldade incontornável, pois nem sempre as retificações posteriores permitem uma identificação exata da carga nos balanços anteriores. Para tanto, seria necessário retornar aos livros originais e construir as fichas individualizadas sugeridas por Carreira, o que atualmente é impossível.

Sendo assim, o modo para avaliar os lucros foi somar o conjunto de estimativas de lucros e as retificações posteriores para, com isto, obter os lucros globais no agregado e nas três rotas do tráfico: LisboaAngola, Pernambuco-Angola, Angola-Pernambuco. Este cálculo é imperfeito, pois nem todas as estimativas foram depois corrigidas nos livros, de modo que para 148 cargas possuímos apenas 127 correções; a contabilidade é interrompida antes de ser esclarecida a totalidade de vendas entre 1759 e 1775 . A maior incongruência, porém, são 26 cargas de Angola para Pernambuco em que o lucro foi lançado diretamente, sem estimativa, de modo que o número de cargas com estimativas de lucro é de apenas 122. A única explicação para tamanha discrepância é que também para os casos em que o lucro foi lançado diretamente ocorreram correções posteriores. Seja como for, tendo em vista que a maior parte das correções era para baixo, este modo de calcular os lucros tende a sobrelevar ligeiramente os lucros porque nem todas as operações registradas e estimadas foram efetivamente retificadas.

A Tabela 3 resume os lucros no conjunto entre 1759-1775, separando-os por rotas, as taxas foram calculadas apenas sobre o valor das cargas.

Estes cálculos confirmam as instruções do copiador de cartas da Junta de Lisboa (ver nota 29), enquanto a venda de mercadorias em

\footnotetext{
39 ANTT, CGPP, Junta de Lisboa, Livros de Demonstrações, L-394.
} 


$\begin{gathered}\text { Tabela 3: Lucro (réis) e taxas de lucro sobre a venda de mercadorias } \\
\text { em Angola e escravos Pernambuco, 1759-1775 } \\
\text { (pelos livros de demonstrações da CGPP). }\end{gathered}$
\begin{tabular}{lrrr} 
Rota & \multicolumn{1}{c}{ Cargas } & \multicolumn{1}{c}{ Lucro } & Taxa \\
\hline $\mathbf{1}$ & 1.109 .600 .301 & 12.414 .745 & $1 \%$ \\
$\mathbf{2}$ & 604.725 .343 & 285.609 .197 & $47 \%$ \\
$\mathbf{3}$ & 120.706 .302 & 18.197 .431 & $15 \%$ \\
$\mathbf{4}$ & 55.239 .896 & 27.442 .018 & $50 \%$ \\
$\mathbf{5}$ & 2.638 .492 & -1.148 .655 & $-44 \%$ \\
Total & 1.892 .910 .334 & 42.514 .736 & $18 \%$ \\
\hline
\end{tabular}

Rota 1: Angola-Pernambuco, rota 2: Lisboa-Angola, rota 3: Pernambuco-Angola, rota 4: Naus da Índia, rota 5: Angola-Rio.

Fonte: ANTT, CGPP, Livros de Demonstrações $(394,395)$.

Angola produzia receitas chorudas, o comércio de escravos propriamente dito era pouco lucrativo; tampouco o negócio de jeribitas produzia muita coisa. Aliás, o que é mais surpreendente é que a venda de mercadorias da Índia, onde foram investidos apenas 55 contos, tenha gerado uma receita superior ao conjunto de exportações de Pernambuco para Angola que movimentou 120 contos e 49 navios (Tabela 3 , rota 4). ${ }^{40}$

No entanto, apenas uma dimensão do negócio é avaliada por estes cálculos, pois não constam aqui os fretes e tampouco são considerados diversos custos. A contabilidade da Companhia calculava os ganhos com fretes separadamente da venda de mercadorias, assim, e apenas até 1769, eram lançados nos lucros ou nos prejuízos as operações referentes ao transporte descontando-se os gastos com o custeamento de cada navio dos ganhos com fretes em cada trajeto (a saber, Lisboa-Angola, Angola-Pernambuco, Pernambuco-Lisboa, Pernambuco-Angola). A partir de 1770 passou-se a registrar, de modo agregado, os lucros e prejuízos líquidos obtidos com a totalidade de operações de frete, incluindo os trajetos do tráfico de escravos e do transporte de açúcar.

\footnotetext{
${ }^{40}$ Não custa lembrar que o livro de demonstrações subestima as exportações de Pernambuco para Angola, mesmo assim se aplicarmos a taxa de $15 \%$ sobre o conjunto das exportações de Pernambuco (ver Tabela 2), chega-se a um valor (em torno de 30 contos) apenas levemente superior ao dos lucros levantados pelas 5 cargas das Naus da Índia.
} 
À primeira vista, os ganhos com fretes parecem ter origem em negócios autônomos, de operações em que a Companhia tivesse apenas carregado mercadorias para terceiros. Ademais, os estatutos definiam uma diferença no que diz respeito à cobrança de fretes sobre as mercadorias da Companhia:

Nas fazendas secas [...] não poderá a Companhia vender por mais de quarenta e cinco por cento, em cima de seu primeiro custo em Lisboa [...] e isto em atenção a que os fretes, seguros, comboios, direitos de entrada e saída, empacamentos, carretos, comissões e mais despesas com as ditas fazendas, hão de ser por conta da Companhia [...]

Nas fazendas molhadas, farinhas, e mais comestíveis [...] não poderá também vender por mais de dezesseis por cento, livres para a Companhia de despesas, fretes, direitos e mais gastos de compras, embarques, entradas e saídas $[\ldots] .^{41}$

Os estatutos, portanto, permitiam a cobrança de fretes apenas nos comestíveis e molhados, enquanto nas fazendas secas o lucro de $45 \%$ deveria absorver os custos. Há uma lacuna na lei no que se refere aos escravos, pois não podiam ser classificados por nenhuma destas categorias.

Mas calculando os valores levantados com fretes no trajeto Angola-Pernambuco entre 1761 e 1769, chega-se à conclusão que eles permitiriam carregar $78 \%$ dos escravos efetivamente carregados para Pernambuco no mesmo período, segundo o TSTD. Como há uma sub-representação dos negócios de escravos nos livros de demonstração, a conclusão é que os valores dos fretes eram obtidos sobre a venda dos escravos da própria Companhia em Pernambuco. Ou melhor, os lucros com fretes eram repassados na venda dos escravos aos compradores de Pernambuco.

A análise dos fretes obtidos entre 1761 e 1769 permite outra conclusão: as maiores rendas com este negócio eram obtidas na rota Angola-Pernambuco e em segundo lugar entre Pernambuco e Angola, como mostra o gráfico 3 :

\footnotetext{
${ }^{41}$ Estatuto da Companhia de Pernambuco e Paraíba, artigo 27, apud: Carreira, As companhias pombalinas, p. 291
} 


\section{Gráfico 3: Lucros brutos apurados com fretes de acordo}

com o trecho da viagem entre 1761 e 1769 pela CGPP

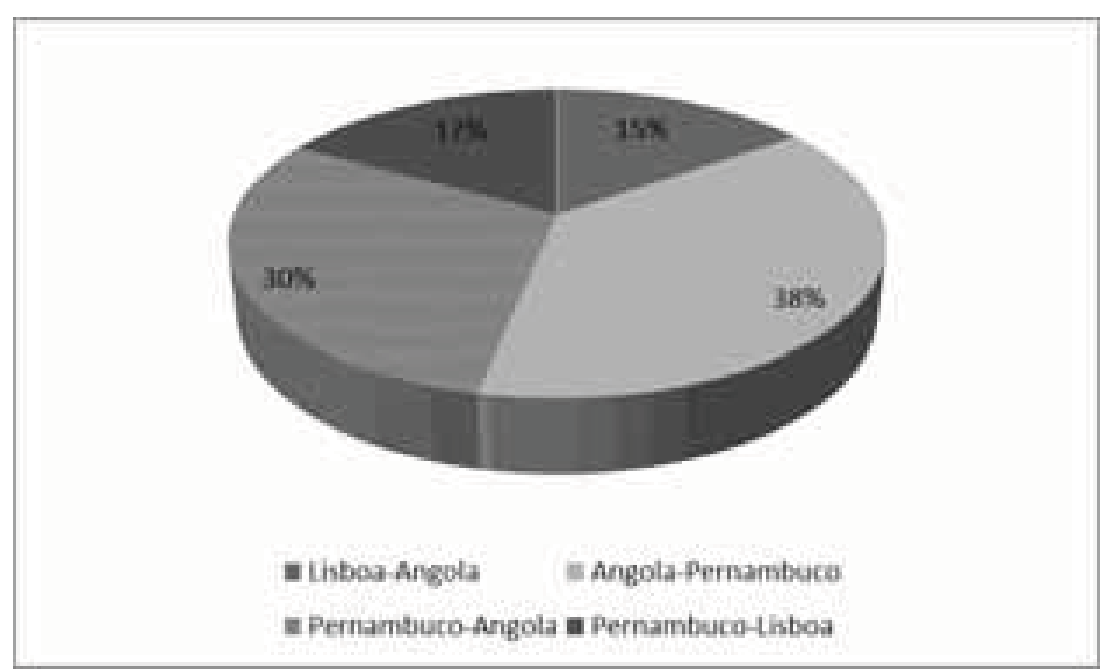

Fonte: ANTT, CGPP, Livros de Demonstrações $(394,395)$.

Ou seja, apesar do baixo volume dos lucros no negócio de mercadorias no conjunto do comércio entre Pernambuco e Angola e da pequena movimentação de mercadorias, particularmente na exportação de produtos americanos para Luanda, os ganhos com fretes acabavam por compensar em parte a manutenção do negócio direto entre África e Brasil. Uma comparação permite visualizar a importância do negócio de fretes: segundo os livros de demonstrações, os valores levantados no trajeto Pernambuco-Angola entre 1761-1769 (73.706.23 réis) superam o valor das mercadorias exportadas por esta rota no mesmo período (73.505.222 réis).

Ao mesmo tempo, vale considerar a pequena importância dos fretes entre Lisboa e Angola: é verdade que, na média por embarcação, os ganhos com o transporte na rota Lisboa-Angola (3.723.244 réis) eram maiores que os do trajeto Pernambuco-Angola (2.541.597 réis). Porém, basta comparar os valores das cargas médias nas duas rotas (respectivamente, 23 e 2,7 contos) para constatar como os fretes eram um negócio secundário na rota do Reino. A explicação está na natureza do negócio: as fazendas trazidas de Portugal possuíam um alto valor e um volume 
Tabela 4: Cálculo da lucratividade das operações de tráfico da Companhia, 1759-1775

\begin{tabular}{lrrr}
\hline & Investimentos & $\begin{array}{c}\text { Lucros } \\
\text { líquidos }\end{array}$ & $\begin{array}{c}\text { Custos } \\
\text { extraordinários }\end{array}$ \\
\hline 1) Mercadorias & 1.892 .910 .334 & & \\
2) Navios & 93.931 .409 & & \\
3) Custeio dos navios & 312.483 .743 & & \\
4) Salários & 1.846 .348 & & \\
5) Venda de mercadorias & & 342.514 .736 & \\
6) Fretes & & 26.336 .212 & \\
7) Mortes em Angola & & & 2.413 .780 \\
Totais & 2.301 .171 .834 & 368.850 .948 & 2.413 .780 \\
Lucros Líquidos-cust os & & 366.437 .168 & \\
Taxa de lucro & & & \\
\hline
\end{tabular}

Fonte: ANTT, CGPP, Livros de Demonstrações $(394,395)$.

muito baixo, já os molhados exportados por Pernambuco eram de baixo valor e volume muito alto. Os já citados estatutos da Companhia refletiam esta diferença entre um e outro negócio.

Passemos agora ao cálculo geral da taxa de lucro das operações da Companhia com o tráfico de Angola entre 1759 e 1775, baseado nos livros de demonstrações (Tabela 4). Para tanto, na coluna "Investimentos" serão somados os valores das cargas (linha 1), os salários dos administradores (linha 4), os preços dos navios utilizados (linha 2) e os custeios das embarcações (linha 3). Na coluna "lucros líquidos" serão lançados os ganhos líquidos sobre as vendas com as mercadorias (linha 5) e os lucros líquidos com os fretes (linha 6), deste valor serão deduzidas algumas perdas com mortes de escravos em Angola (linha 7), coluna "custos extraordinários". Penso que o valor dos navios não pode ser considerado um custo a ser deduzido do lucro líquido, pois faziam parte do "capital fixo" da empresa; o correto seria considerar uma taxa de depreciação, mas creio que esta operação já era abarcada pelos custeamentos (ver adiante). ${ }^{42}$ Mesmo as42 O fato é que os tumbeiros não eram contabilizados como custos nos livros de demonstração e
as suas avaliações mantiveram-se as mesmas entre 1763 e 1775 . 
sim, fiz um segundo cálculo inserindo o valor das embarcações como custos de modo a compensar uma possível depreciação e eventuais custos não contabilizados.

Note-se ainda que os valores dos fretes e do custeio das embarcações só foram discriminados até 1769 , por isto extrapolei a média anual do período 1759-1769 para os anos seguintes (ou seja, até 1775).

Esta conta tem defeitos diversos: nem todo o valor dos navios poderia ser lançado como capital investido no tráfico, pois alguns deles eram utilizados na rota do açúcar. Do mesmo modo, não considerei os fretes ganhos no último trajeto da rota triangular (Pernambuco-Lisboa), pois estavam associados ao negócio do açúcar. ${ }^{43}$ Tal consideração comprime bastante os ganhos com fretes, pois não foi possível descontar os custeamentos especificamente do trajeto entre Pernambuco e Lisboa; ademais a rota triangular, com o retorno a Portugal, era um ganho de escala do tráfico de escravos. ${ }^{44}$ Por último, como já foi dito, uma parte pequena dos ganhos com fretes foi registrada, mesmo para o contexto do livro de demonstrações. Tudo isto leva a concluir que os ganhos no negócio do transporte foram subestimados nesta conta, o que não deixa de ser uma compensação às superestimações dos lucros com o comércio de mercadorias.

Sendo assim, chega-se a uma taxa de lucro de $16 \%$ no conjunto das operações do tráfico (Tabela 4, última linha), se desconsiderado o valor dos navios como um custo, e $12 \%$ se considerados. São, portanto, taxas superiores às calculadas por Robert Stein sobre o tráfico francês $(10 \%)$ e Roger Anstey para o inglês (9,5\%); também superam em muito uma das taxas estimadas por Gustavo Acioli Lopes para a Costa da Mina (3\%). Fica, porém, abaixo dos cálculos de Manolo Florentino $(19,2 \%)$, mas esta última estimativa possui o defeito de uma clara superestimação nos preços dos escravos no Brasil..$^{45}$ Aproxima-se, con-

${ }_{43}$ Por outro lado, levantei apenas 16 embarcações e para duas delas não encontrei os seus respectivos preços.

44 Também retirei desta conta uma operação que estava relacionada a Angola e Costa da Mina e, portanto, poderia distorcer ainda mais as médias.

45 Cf. Acioli Lopes, "Negócio da Costa da Mina", pp. 163-8. O autor sumaria as diversas estimativas da lucratividade do tráfico e apresenta os cálculos mais completos que conheço para o tráfico do Brasil, ainda que baseados em apenas uma embarcação; esta, porém, tratava-se de 
tudo, dos números de Acioli Lopes quando este considera os lucros obtidos com o fretamento (14\%). ${ }^{46}$

Ao comparar os resultados da Companhia com os cálculos de Acioli Lopes, três considerações se impõem: em primeiro lugar, o cálculo do autor sobre a armação é bem mais complexo, incluindo soldadas, mantimentos e a amortização das embarcações. Creio que estes três itens eram cobertos pelo valor do "custeamento" que a contabilidade da empresa lançava junto aos fretes. ${ }^{47} \mathrm{Em}$ segundo lugar, Acioli Lopes lança como custo as perdas de vidas na viagem; como não existem registros destas perdas nos livros de demonstrações, presumo que este valor era deduzido dos lucros com a venda dos escravos em Pernambuco. ${ }^{48}$ Tampouco os gastos com impostos eram registrados, mais um custo que seguramente era deduzido diretamente da realização final da mercadoria humana na América.

A taxa de lucro elevada da Companhia pode ser facilmente explicada como uma renda de monopólio. Não obstante, como já foi dito, o monopólio da empresa era sobre o fornecimento de escravos em Pernambuco, onde os lucros foram estreitos, e não sobre a venda de mercadorias em Angola, onde se concentrava a maior parte dos lucros. A explicação para este problema está na própria organização do negócio que refletia as condições do transporte e a estrutura fiscal do tráfico. Perdas de vidas na viagem do Atlântico e o pagamento de impostos eram um custo importante do negócio: o TSTD registra uma mortalidade de 4,2\% para os navios da Companhia entre 1759 e 1775; mais importante era o peso dos impostos, o valor pago em direitos sobre a exportação de escravos em Angola entre 1759 e 1775 foi de aproximada-

uma viagem “típica”, pois a documentação reunida sobre a embarcação visava informar a Coroa sobre os gastos no tráfico da Costa da Mina. Além disso, o autor retifica os números de Florentino, alcançando uma taxa de $10 \%$.

46 Acioli Lopes, "Negócio da Costa da Mina”, p. 169.

47 Pela "Conta da despesa que se fez com o custeamento da Fragata de Sua Majestade Nossa Senhora da Graça":AHU, Pernambuco, cx.130, doc. 9.832 Joé Cesar de Menezes, 05/09/1778, constata-se que por "custeamento" entendia-se gastos com soldadas, alimentação e hospedagem da tripulação no porto, carpintaria, calafete, mastrearia, reparos em geral, curativos aos doentes e taxas portuárias.

48 È possível, porém, que as perdas de escravos em Angola tenham sido subestimadas na contabilidade da empresa. 
mente $11 \%$ do total do capital investido no tráfico. ${ }^{49}$ Vale dizer, que o peso fiscal em Angola era bem maior do que na Costa da Mina segundo os cálculos de Acioli Lopes (6\%). ${ }^{50}$ Como já foi dito, todos estes custos eram lançados sobre o valor de venda do escravo em Pernambuco, comprimindo a taxa de lucro sobre esta parte do negócio em particular.

Mais uma vez, a prática da Companhia reproduzia o modo de se negociar em Angola: os capitães dos navios costumavam pagar os direitos dos escravos com letras que eram descontadas sobre as vendas destes no Brasil. Apesar de os administradores da Companhia desejarem pagar os direitos de exportação com moedas de cobre, tiveram de se submeter à prática da terra. ${ }^{51}$ Prática, aliás, que era um resultado da separação entre as propriedades das cargas que financiavam o resgate, geralmente de homens de negócio reinóis, e dos escravos que pertenciam à comunidade mercantil de Luanda. ${ }^{52}$ Atuando principalmente no fornecimento de fazendas de resgate, os capitalistas de Lisboa se evadiam dos riscos e dos altos custos do trajeto Angola-Brasil, reproduzindo um tipo de hierarquia econômica e territorial em que o domínio sobre o crédito e sobre a ligação entre a Europa e Angola eram a chave para obter uma lucratividade superior.

De fato, a própria Junta de Lisboa estava consciente deste problema do tráfico em Angola, como mostram as suas queixas sobre a lucratividade da venda com escravos. Em 1768, preocupada com a quantidade de capitais imobilizados em Luanda e com o acúmulo de escravos invendáveis em Pernambuco, escrevia:

\footnotetext{
49 Valor obtido a partir de duas estimativas (259 contos e 242 contos), por não existirem registros sobre os gastos efetivamente feitos nesta operação; as duas estimativas multiplicam um número de escravos exportados pela Companhia pelo direito de 8.700 rs. Mas como há divergência nas fontes sobre o número de escravos, procurei estabelecer um cálculo de controle. Assim, a primeira estimativa foi baseada nos registros dos administradores do contrato de Angola, interpolando as lacunas com os números de Miller (1770) e do TSTD (1768 e 1773) (cf. Tabela 1). A segunda operação foi baseada nos números do TSTD, mas o número de escravos foi descontado em $14 \%$ levando em consideração que o Livro de Demonstrações registra apenas 69 viagens entre Angola e Pernambuco, enquanto que no TSTD constam 80 viagens.

50 Acioli Lopes, "Negócio da Costa da Mina", p. 166.

51 Sobre as letras, cf. AHU, Angola, cx. 52, doc. 58 (consta como sendo posterior a 1768, mas na verdade é do reinado de D. Maria I). Sobre a tentativa dos administradores da Companhia em pagar os direitos com moeda, ver AHU, Angola, cx. 48, doc. 31, Francisco Inocencio Coutinho, 04/08/1764.

52 Cf. Miller, Way of Death, passim.
} 
[...] tem resolvido proporcionar o fundo desta negociação com a saída de gêneros que exporta desse continente, de sorte que não haja excesso na extração, pois que não há uma competente saída. Para este efeito pretende não mandar para essa administração mais fazenda que a que basta para surtir e promover a venda da que lá se acha até chegar ao ponto de existir nessa administração um fundo competente ao negócio que a Companhia deve fazer e das cabeças que aquelas capitanias podem comprar. Neste sistema novo regularão V. Mcê. as suas receitas e igualmente as suas expedições, conferindo com a Direção de Pernambuco o número de cabeças que aquelas capitanias podem comprar. A respeito, porém, da cera V. Mcês. poderão mandar toda a que puderem adquirir por ser este gênero de melhor saída e não ter o risco de se arruinar. Não é a tenção desta Junta diminuir o negócio desse Reino [de Angola] todas as vezes que V. Mcês. se esforçarem em tirar os cabedais, produto das fazendas que remetemos, da mesma sorte que praticavam sempre os negociantes particulares por letras. Isto se entendendo naquele cabedal que exceder o número de cabeças com que se fornecer Pernambuco $[\ldots]^{53}$

Além de procurar reduzir as exportações de escravos para melhorar os preços em Pernambuco, a Junta pretendia realizar os capitais envolvidos no tráfico em cera e letras, de modo a evitar em parte os referidos custos (mortalidade e impostos) com a venda de escravos. Mas a verdade é que a Companhia não podia furtar-se de fornecer escravos e, portanto, tinha de absorver as perdas do Atlântico Sul e as operações com letras e cera, ao que tudo indica foram secundárias.

Ademais, o monopólio sobre o fornecimento de Pernambuco e Paraíba pode ter aumentado de modo indireto os lucros obtidos com as vendas em Angola. Como o lucro em Angola era essencialmente contábil, ou seja, não se transformava em dinheiro líquido, mas apenas em escravos que deveriam ainda ser vendidos em Pernambuco, é possível que fazendas de resgate mais caras comprassem escravos de pior qualidade. ${ }^{54}$ Assim, o alto lucro na venda das fazendas era compensado, no

\footnotetext{
53 ANTT, CGPP, Junta de Lisboa, Copiador de Cartas, L-290, 04/07/1768.

54 No borrador da Junta (ANTT, CGPP, Junta de Lisboa, Copiador de Cartas, L-290) encontramos queixas sobre a qualidade dos escravos nas cartas de 06/11/1761 e 09/04/1783, mas não é possível constatar se isto foi uma constante em todo o período.
} 
outro lado do Atlântico, por ganhos insignificantes ou até mesmo em prejuízos (que seriam ainda maiores na ausência do monopólio). De qualquer modo, o fato é que a Companhia estava ganhando dinheiro com o resgate de escravos angolanos em uma época em que quase todo mundo estava perdendo. ${ }^{55}$

Sendo assim, a CGPP reproduzia alguns dos esquemas de financiamento "típicos" do negócio de Angola, com uma relativa separação entre o fornecimento de mercadorias para o resgate e o transporte de escravos, e um decorrente contraste entre os valores das cargas enviadas de Lisboa e as remetidas do Brasil e de Angola. No entanto, o caráter monopolístico da empresa e a obrigação de fornecer escravos para Pernambuco fazia com que os lucros obtidos em Luanda tivessem de ser realizados em escravos e não preferencialmente em letras, como parece ter sido o caso dos negócios operados pelos negociantes reinóis particulares que enviavam cargas para a praça africana. ${ }^{56}$ Esta particularidade obrigava a Companhia a assumir os riscos com as perdas de escravos na passagem Atlântica e os custos com impostos. Os problemas poderiam ser parcialmente dirimidos graças a uma política de estrangulamento do mercado de Pernambuco visando a manter altos os preços de venda final dos escravos, como parece ter sido a deliberação da Junta de Lisboa em 1768, repassando parte dos custos ao produtor estabelecido no Brasil. Havia, portanto, um aspecto político nos lucros registrados pelos livros de demonstração, dimensionando ganhos altíssimos às cargas originadas em Lisboa e jogando às possessões coloniais os custos da realização das mercadorias.

Cabe abordar um último aspecto da contabilidade da Companhia que permite qualificar a lucratividade e pensar o outro lado dos "lucros políticos" da CGPP: as dívidas. Apesar da Junta de Lisboa instruir a administração de Angola a não vender a crédito, o fato é que isto era

\footnotetext{
55 São muitas as reclamações sobre as condições do negócio de escravos no Brasil durante as décadas de 1760 e 1770, por exemplo, AHU, Angola, cx. 54, doc. 20, Francisco Inocencio Coutinho, 15/03/1770 e, de fato, as exportações de escravos para o Brasil caíram bastante durante a década de 1770. Ver Manolo Florentino, Alexandre Vieira Ribeiro, Daniel Domingues da Silva. "Aspectos comparativos do tráfico de africanos para o Brasil (séculos XVIII e XIX)", Afro-Ásia, n. 31 (2004), pp. 83 - 126, gráfico 1; e Curto, Álcool e escravos, quadros IV e VIII. 56 Miller, Way of death.
} 
impossível e ao que tudo indica a venda a fiado foi amplamente praticada. Estas operações eram por conta dos administradores em Luanda e, portanto, os livros de demonstração registram dívidas exclusivamente da "administração de Angola" e não de particulares como era o caso de Pernambuco. É que, como havia avisado a Junta, eram os administradores que deveriam "responder sobre si" no caso de dívidas.

Nas "Correntes que se acham existir nos balanços demonstrativos desde o princípio da Companhia até 31/12/1775" constavam os seguintes valores em haver:

Cargas de Angola para Pernambuco 97.342 .501 réis.

Cargas de Lisboa para Angola 225.365 .879 réis.

Cargas de Pernambuco para Angola 32.321 .742 réis.

Trata-se de cargas enviadas sobre as quais não existia o registro da venda e que totalizavam mais de 335 contos de réis, valor comparável ao conjunto dos ganhos com o tráfico. Mas isto não pode ser encarado como uma dívida em seu sentido estrito, tendo em vista que elas iam sendo liquidadas à medida que as notícias das vendas chegavam a Lisboa. Tanto é assim que em 1785, ano em que a Junta de Liquidação da Companhia pretendeu encerrar as negociações, as correntes relacionadas ao tráfico em Angola somavam apenas 70 contos de réis. $\mathrm{O}$ fechamento das operações certamente teve reflexos sobre a cobrança da venda de mercadorias, pois em 1793 a Companhia ainda tinha em haver mais de 65 contos de réis em Angola, valor que certamente estava perdido e que poderia ser lançado como prejuízo. ${ }^{57}$

Sendo assim, a presença de mercadorias sem o devido registro de venda em 1785, após sete anos de operações que visavam essencialmente liquidar os negócios, mostra que apesar da lucratividade razoável, o tempo de rotação do capital era extremante alto.

\section{Considerações finais}

Penso que este estudo de caso permite relativizar parte da produção 57 ANTT, CGPP, Junta de Lisboa, Livros de demonstrações, L-395. O valor não foi lançado
como prejuízo no cálculo da lucratividade, pois envolve operações posteriores a 1775 . 
historiográfica dos últimos 20 anos, particularmente no que diz respeito à tese do domínio dos mercadores coloniais sobre o tráfico: a contabilidade da Companhia mostra uma presença avassaladora de cargas de origem reinol no tráfico em Angola, apesar da baixa frequência de embarcações. Os números apresentados comprovam a interpretação de Joseph Miller sobre o tráfico, que vem sendo sistematicamente ignorada pela historiografia brasileira, e os números das balanças de comércio portuguesas e mapas de importação e exportação de Angola entre 1796 e $1807 .{ }^{58}$

Ao mesmo tempo, a importância do mercado de fretes na ligação entre Angola e Pernambuco, aspecto que já havia sido ressaltado por Miller, fica demonstrada quantitativamente. No conjunto, portanto, a participação "brasílica" na balança de pagamentos do tráfico de Angola foi bem maior do que sugere a análise pura dos dados de importação e exportação, mas se fôssemos calcular uma balança de pagamentos seria necessário incluir a diferença na lucratividade das mercadorias que, como foi visto, favorecia a metrópole. Penso que aqui é possível uma aproximação com a historiografia recente, desde que devidamente qualificada: o domínio brasileiro era sobre o "tráfego" de Angola e não sobre o "tráfico" de Angola, para utilizar uma importante distinção conceitual sugerida por Leonor da Freire Costa. ${ }^{59} \mathrm{O}$ negócio do transporte era uma atividade importantíssima, como mostram os expressivos ganhos com fretes da CGPP; caberia um estudo dos efeitos de encadeamento deste sobre a construção naval e a produção de alimentos para a matalotagem no Brasil, seguindo aqui uma via de análise explorada por Amaral Lapa em seu estudo sobre a Carreira da Índia. ${ }^{60}$

Outra aproximação, mas aqui se trata mais dos trabalhos da historiografia anglo-saxã, diz respeito ao cálculo da lucratividade do tráfico. Ao contrário do que presumia o velho Eric Wiiliams, a lucratividade do tráfico era "normal", mesmo para uma companhia monopolista. O

\footnotetext{
Cf. Menz, "As 'geometrias' do tráfico".

9 Leonor Costa, O transporte no Atlântico e a Companhia Geral do Comércio do Brasil, 15801663, Lisboa: CNCDP, 2002.

${ }^{60}$ José R. Lapa, A Bahia e Carreira da Índia, São Paulo/Campinas: Hucitec/Editora da UNICAMP, 2000
} 
resultado entre 12 e 16\% aproxima-se dos cálculos rigorosos de Acioli Lopes para o Atlântico lusitano, Anstey para o Atlântico inglês e Stein para o Atlântico francês. Mas vale lembrar que esta lucratividade merece ser comparada com outras alternativas de investimentos numa economia de Antigo Regime. Stuart Schwartz estimou uma taxa de retorno entre 5 e $10 \%$ para os engenhos baianos durante o século XVIII; já Helen Osório calculou taxas de lucro entre $61,6 \%, 75 \%$ e $110,6 \%$ de alguns contratos do Rio Grande do Sul no final do século XVIII, no conjunto das operações, por sua vez, Acioli Lopes encontrou taxas bem menos significativas para o dízimo do açúcar na primeira metade do século XVIII, entre 1 e $4,6 \%$ anual. ${ }^{61}$

As receitas obtidas pela Companhia com o tráfico são menores apenas do que os lucros obtidos com os contratos do Rio Grande no final do século XVIII, mas são conjunturas distintas, considerando que a Companhia operou durante uma depressão comercial, sua taxa de lucro parece ser ainda mais formidável. O tráfico em Angola era, no final das contas um interessante vent for profit para o capital mercantil metropolitano.

Texto recebido em 24 de outubro de 2011 e aprovado em 16 de outubro de 2012.

\footnotetext{
${ }^{61}$ Cf. Stwart Schwartz, Segredos internos, p. 204; e Helen Osório, "Estancieiros, lavradores e comerciantes na constituição da extremadura portuguesa na América: Rio Grande de São Pedro, 1737-1822" (Tese de Doutorado, Universidade Federal Fluminense, 1999), pp. 223-6. Acioli Lopes, "Negócio da Costa da Mina", p. 26.
} 


\section{Resumo}

Através da análise dos livros contábeis da Companhia de Pernambuco e da Paraíba, o artigo apresenta estimativas sobre o negócio de importações e a lucratividade do tráfico em Angola operado pela Companhia. Por este estudo de caso procura-se desenvolver a hipótese formulada originalmente por Joseph Miller de que era a metrópole que financiava a maior parte do tráfico em Angola. Deste modo, pretende-se discutir o funcionamento do tráfico de escravos nesta região, particularmente no que diz respeito às operações de financiamento e de transporte.

Palavras chave: tráfico de escravos - Companhia de Pernambuco - Angola crédito - transporte.

\section{Abstract}

By analyzing the Pernambuco \& Paraiba Company's books, this article presents estimates about the importations and profitability of the slave trade in Angola, operated by the Company. This case study seeks to develop a hypothesis originally formulated by Joseph Miller that it was the metropolis that financed most of trade in Angola. Thus, we intend to discuss the operation of the slave trade in the region, particularly with regard to financing and transport operations.

Keywords: Slave trade - Pernambuco Company-Angola-credit-transport. 